\title{
High salt intake increases endothelin B receptor function in the renal medulla of rats
}

\author{
Chunhua Jin, Joshua S. Speed, and David M. Pollock \\ Cardio-Renal Physiology and Medicine, Divisionf of Nephrology, Department of Medicine, \\ University of Alabama at Birmingham, Birmingham, AL
}

\begin{abstract}
Aims-Endothelin (ET)-1 promotes natriuresis via the endothelin $\mathrm{B}$ receptor $\left(\mathrm{ET}_{\mathrm{B}}\right)$ within the renal medulla. In male rats, direct interstitial infusion of ET-1 into the renal medulla has no effect on renal sodium and water excretion but is associated with endothelin $\mathrm{A}$ receptor $\left(\mathrm{ET}_{\mathrm{A}}\right)$-dependent reductions in medullary blood flow. Loss of $\mathrm{ET}_{\mathrm{B}}$ function leads to salt-sensitive hypertension. We hypothesized that HS intake would increase the natriuretic and diuretic response to renal medullary infusion of ET peptides.
\end{abstract}

Main methods-Male Sprague Dawley (SD) rats were fed a normal (NS) or high (HS) salt diet for 7 days. Rats were anesthetized and a catheter implanted in the renal medulla for interstitial infusion along with a ureteral catheter for urine collection. Medullary infusion of a low dose of $\mathrm{ET}_{\mathrm{B}}$ receptor agonist, sarafotoxin $6 \mathrm{c}(\mathrm{S} 6 \mathrm{c} ; 0.15 \mu \mathrm{g} / \mathrm{kg} / \mathrm{h})$, or ET-1 $(0.45 \mu \mathrm{g} / \mathrm{kg} / \mathrm{h})$ was used to determine changes in sodium excretion ( $\mathrm{UNaV})$.

Key findings-In HS fed rats, intramedullary infusion of a low dose of S6c induced a significant increase in $\mathrm{UNaV}$, roughly 2 -fold over baseline, compared to no response to this low dose in NS fed rats. In HS fed rats, intramedullary infusion of ET-1 induced a significantly greater increase in $\mathrm{UNaV}$ compared to NS fed rats, although this increase was not different from the HS time control studies.

Significance-We conclude that high salt intake enhances the diuretic and natriuretic effects of $\mathrm{ET}_{\mathrm{B}}$ receptor activation in vivo consistent with a role for the $\mathrm{ET}_{\mathrm{B}}$ receptor in maintaining fluidelectrolyte homeostasis.

\section{Keywords}

endothelin receptor; high salt; natriuresis; diuresis

Corresponding author: David M. Pollock, Ph.D., Cardio-Renal Physiology and Medicine, Division of Nephrology, Department of Medicine, University of Alabama at Birmingham, Birmingham, AL 35233, Phone: 205-975-7526, Fax: 205-975-7520, dpollock@uab.edu.

Conflict of Interest Statement

The authors declare that there are no conflicts of interest. 


\section{Introduction}

The renal endothelin (ET) system plays important role for maintaining renal vascular and tubular function, water and sodium balance as well as blood pressure control (Kohan et al., 2011). In brief, ET-1 acts via two distinct G-protein coupled receptors, $\mathrm{ET}_{\mathrm{A}}$ and $\mathrm{ET}_{\mathrm{B}}$, which are highly expressed in the kidney (Gellai et al., 1994). In renal vasculature, smooth muscle cells express both $\mathrm{ET}_{\mathrm{A}}$ and $\mathrm{ET}_{\mathrm{B}}$, which mediate a direct vasoconstrictor action of ET-1, although the level of $\mathrm{ET}_{\mathrm{B}}$ expression is very low in most vessel types. Endothelial cells express $\mathrm{ET}_{\mathrm{B}}$ receptors, which exert vasodilator effects via the release of nitric oxide $(\mathrm{NO})$ and prostacyclin. In the renal medulla, $\mathrm{ET}_{\mathrm{B}}$ receptors are expressed on endothelial cells of the vasa recta while $\mathrm{ET}_{\mathrm{A}}$ receptors are on pericytes that can contract or relax to regulate blood flow (Crawford et al., 2012). However, the highest level of expression are $\mathrm{ET}_{\mathrm{B}}$ receptors in the inner medullary collecting duct (Gellai et al., 1994, Kohan et al., 2011). Kohan and colleagues have demonstrated that collecting duct ET-1 functions to activate $\mathrm{ET}_{\mathrm{B}}$ receptors to reduce activity of the epithelial $\mathrm{Na}^{+}$channel $(\mathrm{ENaC})$ in this nephron segment (Ahn et al., 2004, Bugaj et al., 2012, Ge et al., 2005, Ge et al., 2006). Importantly, collecting duct specific ET-1 and $\mathrm{ET}_{\mathrm{B}}$ receptor knockout mice have elevated blood pressures that become exacerbated by a high salt diet (Ahn et al., 2004, Ge et al., 2006). Urinary excretion of ET-1, an index of elevated production (Pollock and Pollock, 2001) is significantly reduced in collecting duct-specific ET-1 knockout mice (Ahn et al., 2004).

ET-1 production is elevated during high salt (HS) intake and dysregulation of this system leads to salt-sensitive hypertension. Gariepy et al first demonstrated that rats deficient in the $\mathrm{ET}_{\mathrm{B}}$ receptor display salt-sensitive hypertension (Gariepy et al., 2000). Similarly, chronic $\mathrm{ET}_{\mathrm{B}}$ receptor blockade leads to salt-sensitive hypertension (Pollock and Pollock, 2001). Our laboratory has previously shown that infusion of ET-1 into the renal medullary interstitium has no effect on urine flow (UV) and sodium excretion (UNaV) in male rats on a normal salt diet, while infusion of an $\mathrm{ET}_{\mathrm{B}}$ receptor agonist, sarafotoxin 6c (S6c), increases UV and $\mathrm{UNaV}$ with a dose of $(0.45 \mu \mathrm{g} / \mathrm{kg} / \mathrm{hr})$ but not with a relatively low dose of $0.15 \mu \mathrm{g} / \mathrm{kg} / \mathrm{hr}$ (Nakano et al., 2008). ET-1, but not S6c, was associated with a decrease in medullary blood flow. We have also observed that infusion of the ET-1 precursor, Big ET-1, results in an increase in medullary blood flow in animals on a high salt, but not normal salt diet (Vassileva et al., 2003). These data are consistent with an increase in $\mathrm{ET}_{\mathrm{B}}$ receptor function within the renal medulla. Therefore, we tested the hypothesis that high salt intake would increases the diuretic and natriuretic effects of renal medullary $\mathrm{ET}_{\mathrm{B}}$ receptor stimulation in vivo. We utilized male Sprague-Dawley rats, and medullary infusion of a relatively low dose of S6c or ET-1, to determine if high salt feeding increases $\mathrm{ET}_{\mathrm{B}}$ dependent urine volume and sodium excretion.

\section{Materials and methods}

All studies used 10 12 week old male Sprague-Dawley (SD) rats obtained from Harlan Laboratories (Indianapolis, IN, USA). Animals were housed in temperature and humidity controlled, $12 \mathrm{~h}: 12 \mathrm{~h}$ light-cycled quarters and maintained on a standard rat chow containing $0.49 \% \mathrm{NaCl}$ (NS, normal salt; Harlan Cat. \#TD96208) with free access to water. Separate groups of rats were given a high salt diet (HS, $4 \% \mathrm{NaCl}$, Harlan Cat. \#TD92034) for one 
week before the acute experiments described below. All experiments and procedures were approved and monitored by the Institutional Animal Care and Use Committee in accordance with the National Institutes of Health guidelines.

\section{Surgical preparation}

Rats were anesthetized with inactin (100 mg/kg, i.p.), and placed on a thermostatically controlled surgical table. The trachea was cannulated to facilitate free breathing. The left femoral artery was catheterized for monitoring blood pressure using a MacLab data acquisition system (AD Instruments), and the left femoral vein was catheterized for infusion of $3 \%$ bovine albumin in isotonic saline $(0.9 \% \mathrm{NaCl})$ at a rate of $20 \mu \mathrm{L} / \mathrm{min}$ to maintain euvolemia. The left kidney was then exposed from a flank incision, and an interstitial infusion catheter was inserted into the renal medulla (stretched PE-10). Isotonic saline was infused directly into the renal medullary interstitium at a rate of $0.5 \mathrm{~mL} / \mathrm{h}$ for duration of the experiment. An adjustable occluder was placed around the abdominal aorta just proximal to the left renal artery to maintain renal perfusion pressure (RPP) constant throughout the study based on the blood pressure observed at the end of the surgical recovery period. The left ureter was cannulated with stretched PE-10 for urine collection with urine volume determined gravimetrically and sodium concentration measured by atomic absorption spectrometer (iCE 3000, Thermo Scientific). At the end of each experiment, the kidney was dissected to ensure that the catheter was in the appropriate position within the medulla roughly at the junction between the outer and inner medulla.

Following surgical preparation, all animals were subjected to a 60 90 min equilibration period followed by one $40 \mathrm{~min}$ control urine collection period, in which isotonic saline was continuously infused into the renal medullary interstitium at a rate of $0.5 \mathrm{ml} / \mathrm{hr}$. This was followed by two additional 40 min experimental urine collection periods. Rats on both normal and high salt diets were divided into three groups in which either normal saline (time control), low dose S6c (0.15 $\mu \mathrm{g} / \mathrm{kg} / \mathrm{hr}$, in saline), or ET-1 (0.45 $\mu \mathrm{g} / \mathrm{kg} / \mathrm{hr}$, in saline) was infused into the medullary interstitium during the experimental periods. We previously reported that S6c produced a significant natriuresis in rats on a NS diet at a dose of 0.45 $\mu \mathrm{g} / \mathrm{kg} / \mathrm{hr}$, but lower doses were less effective (Kittikulsuth et al., 2011, 2012, Nakano et al., 2008). Since we expected to see a more robust natriuresis, we used a lower dose of S6c. Since ET-1 at $0.45 \mu \mathrm{g} / \mathrm{kg} / \mathrm{hr}$ had no effect on $\mathrm{UNaV}$ in rats on NS, we used the same dose in the current studies.

\section{Receptor binding assay}

In a separate series of animals maintained on a high salt diet, inner medullas were homogenized in buffer (50 mM Tris-HCl, $5 \mathrm{mM}$ EDTA, $250 \mathrm{mM}$ sucrose, $15 \mu \mathrm{M}$ PMSF, $\mathrm{pH}$ 7.4) with $1.3 \mathrm{mM}$ phenylmethanesulfonyl (PMSF). Samples were spun at $1000 \mathrm{~g}$ for 30 minutes at $4^{\circ} \mathrm{C}$. The supernatant containing membrane fraction was centrifuged at $30,000 \mathrm{~g}$ and $4^{\circ} \mathrm{C}$ for 45 minutes to pellet membranes. The supernatant was discarded and the pellet (cell membrane enriched) was suspended in $100 \mu \mathrm{l}$ of homogenization buffer and disrupted. Total protein was measured using the Bradford method The binding assay was performed in duplicate on a 96-well Packard Optiplate. Samples were diluted in binding buffer $(20 \mathrm{mM}$ Tris-HCl, $100 \mathrm{mM} \mathrm{NaCl}, 10 \mathrm{mM} \mathrm{MgCl} 2,3 \mathrm{mM}$ EDTA, $0.1 \mathrm{mM}$ PMSF, $5 \mu \mathrm{g} / \mathrm{mL}$ pepstatin 
A, $0.025 \%$ bacitracin, $0.2 \% \mathrm{BSA}$ ) to a final protein concentration of $0.3 \mu \mathrm{g} / 50 \mu \mathrm{l} .50 \mu \mathrm{l}$ of sample and $25 \mu \mathrm{l}$ of $40 \mathrm{mg} / \mathrm{ml}$ wheatgerm agglutinin coated PVT SPA beads (Perkin Elmer) were added to each well. The plate was incubated on a shaker for 3 hours at room temperature. Total binding was determined by adding $50 \mu \mathrm{l}$ of 125I-ET-1 (Perkin Elmer, Waltham, Ma) to each well at final concentrations of 1.0, 0.6, 0.3, 0.1, 0.06, $0.03 \mathrm{nM}$. Nonspecific binding was determined by adding $10 \mu \mathrm{M}$ of non-labeled ET-1 (American Peptide, Sunnyvale, CA) to the total binding mix. The plates were incubated on a shaker for $18 \mathrm{~h}$ at room temperature, and scintillation was measured using a Packard Top Count apparatus.

\section{Statistical analysis}

Data are presented as means \pm SE. Comparisons from baseline to second 40 min drug infusion period among NS or HS treated rats were performed by two-way ANOVA followed by Bonferroni post hoc tests. Binding data were compared using Student's t-test. Non-linear regression was used to determine Bmax of ET-1 specific binding (GraphPad Prism 6.0). Differences were considered statistically significant at $P<0.05$.

\section{Results}

In the time control animals maintained on a normal salt diet (Fig. 1A), urinary excretion of sodium $(\mathrm{UNaV})$ was not significantly different between control and experimental periods $(0.50 \pm 0.12$ to $0.59 \pm 0.10 \mu \mathrm{mol} / \mathrm{min}, \mathrm{n}=11)$. However, in time control animals on a high salt diet, $\mathrm{UNaV}$ significantly increased from $0.85 \pm 0.06$ to $1.31 \pm 0.10 \mu \mathrm{mol} / \mathrm{min}(P<0.05, \mathrm{n}=9)$. There were no significant changes in urine volume (UV) in time control animals whether on a NS or HS diet (Fig. 1B). RPP was maintained constant as in all experimental groups (Fig. $1 \mathrm{C})$.

In the S6c infused rats, $\mathrm{UNaV}$ significantly increased from $0.87 \pm 0.12$ to $1.98 \pm 0.18$ $\mu \mathrm{mol} / \mathrm{min}$ in HS fed rats $(P<0.05)$ but not NS fed rats $(0.46 \pm 0.09$ to $0.49 \pm 0.07 \mu \mathrm{mol} / \mathrm{min})$ (Fig. 1D). Similar increases were observed in the UV responses of HS fed rats, which rose from $5.0 \pm 0.5$ to $28.3 \pm 3.4 \mu \mathrm{L} / \mathrm{min}$ but only $7.2 \pm 1.7$ to $10.4 \pm 1.0 \mu \mathrm{L} / \mathrm{min}$ in NS fed rats (Fig. 1E). RPP was maintained constant (Fig. 1F). Additionally, in HS fed rats, the increase of $\mathrm{UNaV}$ and UV response to a relatively low dose of S6c were significantly greater than in the HS time control studies $(P<0.05)$.

Intramedullary ET-1 infusion increased $\mathrm{UNaV}$ from $0.90 \pm 0.21$ to $1.50 \pm 0.23 \mu \mathrm{mol} / \mathrm{min}$ in $\mathrm{HS}$ fed rats $(P<0.05)$ but only $0.40 \pm 0.08$ to $0.69 \pm 0.17 \mu \mathrm{mol} / \mathrm{min}$ in NS fed rats (Fig. 1G). There were no significant changes of urine volume (UV) either NS or HS fed rats (Fig 1H). RPP was maintained constant (Fig. 1I). Also, in HS fed rats, the increase of UNaV response to ET-1 was not significantly different from the HS time control studies.

In a separate group of animals, inner medullary tissue was removed and membrane preparations used to assess total ET-1 binding as previously described (Kittikulsuth et al., 2011, Taylor et al., 2002). Fig. 2 shows that total ET-1 binding was significantly increased in rats on a HS versus NS diet $(P<0.05)$. 


\section{Discussion}

The major question addressed in the present study was whether high salt intake would enhance the diuretic and natriuretic effects of $\mathrm{ET}_{\mathrm{B}}$ receptor activation in vivo. Our studies demonstrate that direct intramedullary stimulation of $\mathrm{ET}_{\mathrm{B}}$ receptors with a relatively low dose of the $\mathrm{ET}_{\mathrm{B}}$ agonist, $\mathrm{S} 6 \mathrm{c}$, produced a dramatic diuretic and natriuretic response in the high salt fed rats. However, the overall natriuretic response to direct intramedullary infusion of ET-1 was not different from the response in the time control saline infused animals. This is consistent with ET-1 dependent $\mathrm{ET}_{\mathrm{A}}$ activity counteracting $\mathrm{ET}_{\mathrm{B}}$ function when exogenous ET-1 is infused into the renal medullary interstitium as we have previously reported in animals on a normal salt diet (Nakano et al., 2008).

Our findings of elevated $\mathrm{ET}_{\mathrm{B}}$ dependent natriuresis under high salt diet conditions are consistent with a role for the ET-1/ET $\mathrm{B}$ pathway in facilitating the excretion of a high salt diet. Both human and animal studies have demonstrated an association between urinary ET-1 excretion and salt intake (Jackson et al., 2001, Pollock and Pollock, 2001). Importantly, collecting duct specific knockout of ET-1 expression significantly reduces ET-1 excretion (Ahn et al., 2004). Both in vivo and in vitro studies have demonstrated that the $\mathrm{ET}_{\mathrm{B}}$ receptor signals through NO synthase 1 (NOS1) (Hyndman et al., 2013a, Hyndman et al., 2015, Nakano et al., 2008, Stricklett et al., 2006). Hyndman and colleagues demonstrated that collecting duct NOS1 activity is increased in collecting ducts from animals on a high salt diet (Hyndman et al., 2013b), and recently reported that CD NOS1 is critical for the ET-1dependent inhibition of the epithelium sodium channel (ENaC) (Hyndman et al. 2015). Taken together, we suspect the increase in NO-dependent inhibition of the epithelial $\mathrm{Na}^{+}$ channel in the collecting duct may explain our current findings of increased $\mathrm{ET}_{\mathrm{B}}$ dependent natriuresis in rats on a high salt diet. Changes in renal perfusion pressure cannot explain our results given that MAP was maintained constant throughout our experiments. It is also worth noting that SD rats are not salt-sensitive and had no significant effect on resting blood pressure at least as measured in our anesthetized animals.

Our group previously reported that a $\mathrm{HS}$ diet increased renal vascular $\mathrm{ET}_{\mathrm{B}}$ receptor expression (Schneider et al., 2007). More recently, Fellner et al observed that increased ET $_{B}$ receptor dependent effects in rats on a high salt diet accounts for a loss of pre-glomerular autoregulatory behavior in animals on a HS diet consistent with increased vasodilator activity (Fellner et al., 2015). Our data demonstrated elevated total ET-1 binding in renal inner medullary membrane preparations, which are predominantly $\mathrm{ET}_{\mathrm{B}}$ receptors, are consistent with HS-dependent increases in $\mathrm{ET}_{\mathrm{B}}$ expression and activity.

Our laboratory has used the intramedullary infusion technique to examine receptor-specific effects of ET peptides in a variety of studies (Kittikulsuth et al., 2011, 2012, Nakano and Pollock, 2009, Nakano et al., 2008). The dose of S6c and ET-1 in prior studies was 0.45 $\mu \mathrm{g} / \mathrm{kg} / \mathrm{hr}$ into the medullary interstitial space. Under NS conditions, this dose of the $\mathrm{ET}_{\mathrm{B}}$ agonist produced a significant natriuresis, while lower doses were less effective similar to what we observed in the current study at a dose of $0.15 \mu \mathrm{g} / \mathrm{kg} / \mathrm{hr}$. Our observations that ET-1 was less effective than S6c even under conditions of high salt intake suggests that exogenous ET-1 activates $\mathrm{ET}_{\mathrm{A}}$ receptors that remain in opposition to $\mathrm{ET}_{\mathrm{B}}$-dependent natriuresis. We 
conclude that high salt intake enhances the diuretic and natriuretic effects of $\mathrm{ET}_{\mathrm{B}}$ receptor activation in vivo consistent with a role for the $\mathrm{ET}_{\mathrm{B}}$ receptor in maintaining fluid-electrolyte balance in response to elevations in dietary salt.

\section{Acknowledgments}

The authors would like to express our gratitude to Drs. Kelly A. Hyndman and Jennifer S. Pollock for helpful discussions and advice in the preparation of this manuscript. This work was supported by the program project grant on the Endothelin Control of Renal Hemodynamic and Excretory Function (P01 HL-95499) funded by the National Heart, Lung and Blood Institute.

\section{References}

Ahn D, Ge Y, Stricklett PK, Gill P, Taylor D, Hughes AK, et al. Collecting duct-specific knockout of endothelin-1 causes hypertension and sodium retention. J Clin Invest. 2004; 114:504-11. [PubMed: 15314687]

Bugaj V, Mironova E, Kohan DE, Stockand JD. Collecting duct-specific endothelin B receptor knockout increases ENaC activity. Am J Physiol Cell Physiol. 2012; 302:C188-94. [PubMed: 21918182]

Crawford C, Kennedy-Lydon T, Sprott C, Desai T, Sawbridge L, Munday J, et al. An intact kidney slice model to investigate vasa recta properties and function in situ. Nephron Physiol. 2012; 120:p17-31. [PubMed: 22833057]

Fellner RC, Guan Z, Cook AK, Pollock DM, Inscho EW. Endothelin Contributes to Blunted Renal Autoregulation Observed with a High Salt Diet. Am J Physiol Renal Physiol. 2015 ajprenal 00641 2014.

Gariepy CE, Ohuchi T, Williams SC, Richardson JA, Yanagisawa M. Salt-sensitive hypertension in endothelin-B receptor-deficient rats. J Clin Invest. 2000; 105:925-33. [PubMed: 10749572]

Ge Y, Ahn D, Stricklett PK, Hughes AK, Yanagisawa M, Verbalis JG, et al. Collecting duct-specific knockout of endothelin-1 alters vasopressin regulation of urine osmolality. Am J Physiol Renal Physiol. 2005; 288:F912-20. [PubMed: 15632412]

Ge Y, Bagnall A, Stricklett PK, Strait K, Webb DJ, Kotelevtsev Y, et al. Collecting duct-specific knockout of the endothelin B receptor causes hypertension and sodium retention. Am J Physiol Renal Physiol. 2006; 291:F1274-80. [PubMed: 16868309]

Gellai M, DeWolf R, Pullen M, Nambi P. Distribution and functional role of renal ET receptor subtypes in normotensive and hypertensive rats. Kidney Int. 1994; 46:1287-94. [PubMed: 7853786]

Hyndman KA, Boesen EI, Elmarakby AA, Brands MW, Huang P, Kohan DE, et al. Renal collecting duct NOS1 maintains fluid-electrolyte homeostasis and blood pressure. Hypertension. 2013a; 62:91-8. [PubMed: 23608660]

Hyndman KA, Bugaj V, Mironova E, Stockand JD, Pollock JS. NOS1-dependent negative feedback regulation of the epithelial sodium channel in the collecting duct. Am J Physiol Renal Physiol. 2015; 308:F244-51. [PubMed: 25391901]

Hyndman KA, Xue J, MacDonell A, Speed JS, Jin C, Pollock JS. Distinct regulation of inner medullary collecting duct nitric oxide production from mice and rats. Clin Exp Pharmacol Physiol. 2013b; 40:233-9. [PubMed: 23331097]

Jackson RW, Treiber FA, Harshfield GA, Waller JL, Pollock JS, Pollock DM. Urinary excretion of vasoactive factors are correlated to sodium excretion. Am J Hypertens. 2001; 14:1003-6. [PubMed: 11710777]

Kittikulsuth W, Pollock JS, Pollock DM. Sex differences in renal medullary endothelin receptor function in angiotensin II hypertensive rats. Hypertension. 2011; 58:212-8. [PubMed: 21646601]

Kittikulsuth W, Pollock JS, Pollock DM. Loss of renal medullary endothelin B receptor function during salt deprivation is regulated by angiotensin II. Am J Physiol Renal Physiol. 2012; 303:F659-66. [PubMed: 22674027]

Kohan DE, Rossi NF, Inscho EW, Pollock DM. Regulation of blood pressure and salt homeostasis by endothelin. Physiol Rev. 2011; 91:1-77. [PubMed: 21248162] 
Nakano D, Pollock DM. Contribution of endothelin A receptors in endothelin 1-dependent natriuresis in female rats. Hypertension. 2009; 53:324-30. [PubMed: 19104001]

Nakano D, Pollock JS, Pollock DM. Renal medullary ET $_{\mathrm{B}}$ receptors produce diuresis and natriuresis via NOS1. Am J Physiol Renal Physiol. 2008; 294:F1205-11. [PubMed: 18305094]

Pollock DM, Pollock JS. Evidence for endothelin involvement in the response to high salt. Am J Physiol Renal Physiol. 2001; 281:F144-50. [PubMed: 11399655]

Schneider MP, Inscho EW, Pollock DM. Attenuated vasoconstrictor responses to endothelin in afferent arterioles during a high-salt diet. Am J Physiol Renal Physiol. 2007; 292:F1208-14. [PubMed: 17213466]

Stricklett PK, Hughes AK, Kohan DE. Endothelin-1 stimulates NO production and inhibits cAMP accumulation in rat inner medullary collecting duct through independent pathways. Am J Physiol Renal Physiol. 2006; 290:F1315-9. [PubMed: 16380457]

Taylor TA, Gariepy CE, Pollock DM, Pollock JS. Unique endothelin receptor binding in kidneys of ET $_{\mathrm{B}}$ receptor deficient rats. Am J Physiol Regul Integr Comp Physiol. 2002; 7:7.

Vassileva I, Mountain C, Pollock DM. Functional role of $\mathrm{ET}_{\mathrm{B}}$ receptors in the renal medulla. Hypertension. 2003; 41:1359-63. [PubMed: 12719443] 

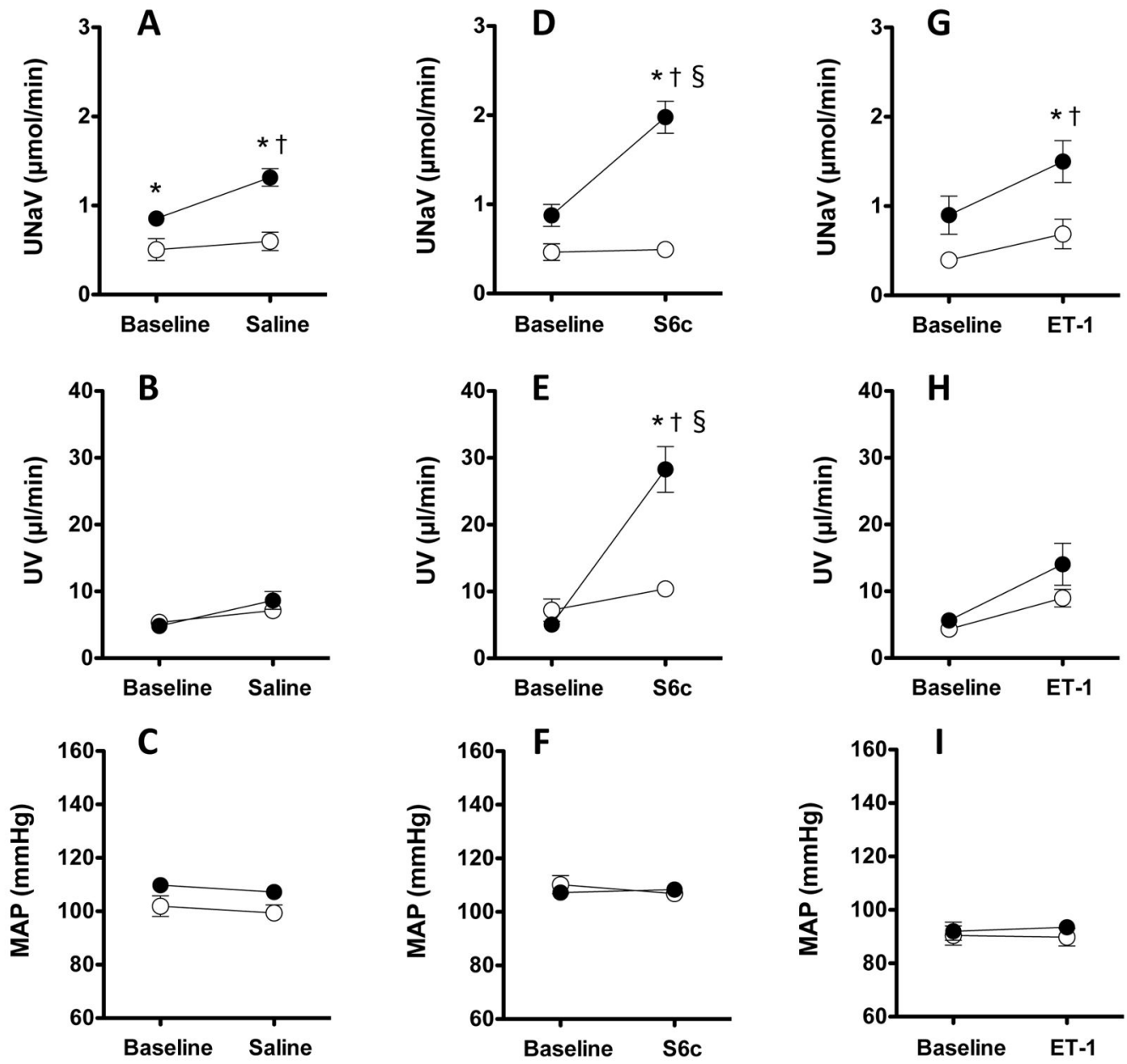

Figure 1.

Sodium excretion (A, D, G), urine flow $(\mathrm{B}, \mathrm{E}, \mathrm{H})$ and mean arterial pressure $(\mathrm{C}, \mathrm{F}, \mathrm{I})$ during a baseline period and the $2^{\text {nd }}$ experimental period of intramedullary infusion of saline $(A-C)$ or S6c (D-F) or ET-1 (G-I) in anesthetized Sprague-Dawley rats. Black symbols denote high salt (HS) fed rats and white symbols denote normal salt (NS) fed rats. $* P<0.05$ vs NS for the same time; ${ }^{\dagger} P<0.05$ vs baseline period; $\S P<0.05$ vs HS time control group. $n=$ $8 \sim 11$ each group. 

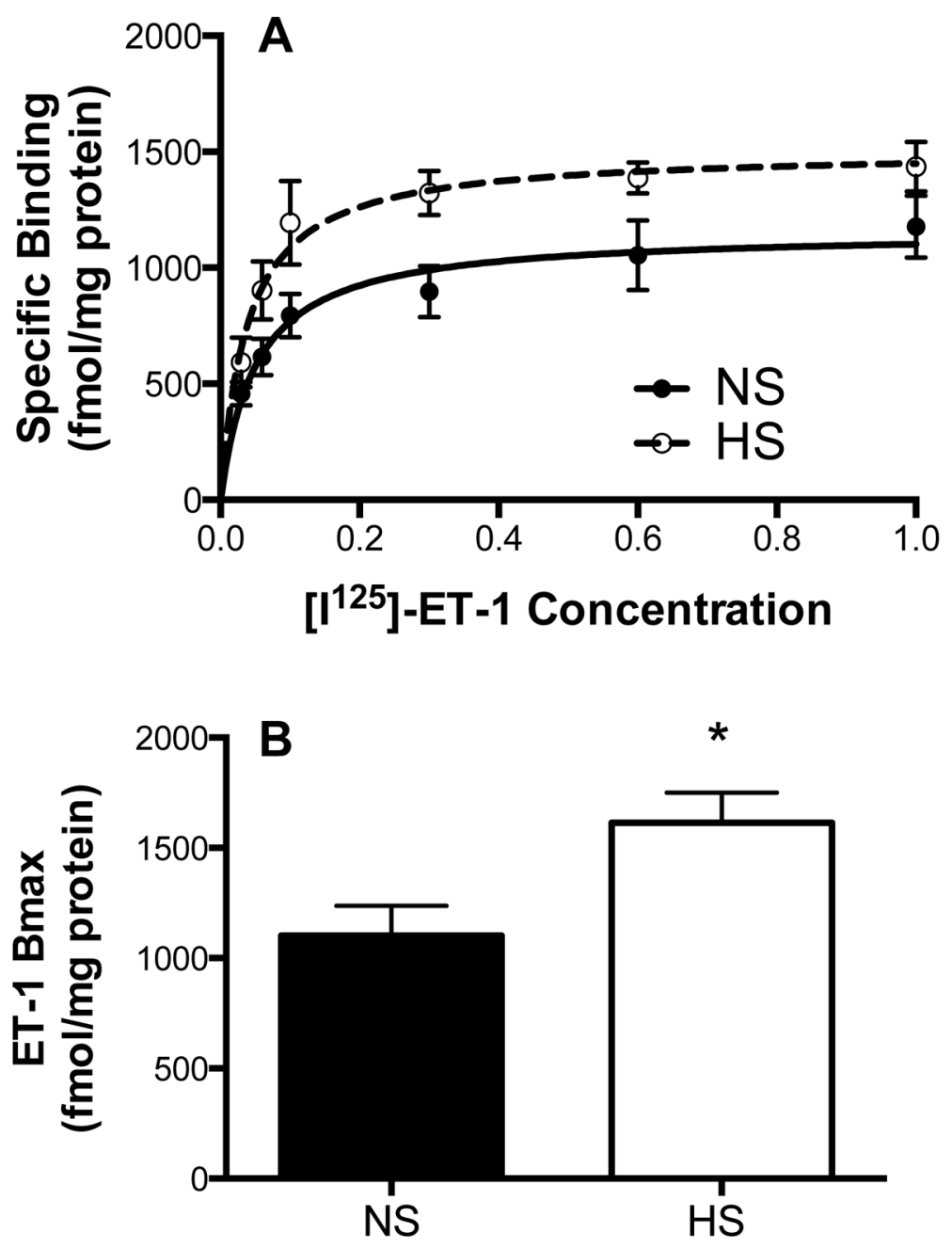

Figure 2.

Saturation binding curves (A) and maximum binding (Bmax) (B) for $\left[{ }^{125} \mathrm{I}\right]-\mathrm{ET}-1$ in plasma membrane preparations from renal inner medullary tissue taken from rats on a normal salt (NS) or high salt (HS) diet; $\mathrm{n}=6,5$ rats, respectively. $* P<0.05$ vs NS 